\title{
KORELASI PERSEPSI DOSEN TERHADAP KEMAMPUAN MANEGERIAL DEKAN DENGAN MOTIVASI BERPRESTASI DOSEN DI LINGKUNGAN UNIVERSITAS BATANGHARI
}

\author{
Jonner Simarmata ${ }^{1}$
}

\begin{abstract}
It is believed that managerial skills of a leader significantly affect the motivation of employees. This research aims at finding whether or not deans' managerial skills of Pedagogics Faculty $\left(X_{1}\right)$, Economics Faculty $\left(X_{2}\right)$, Law Faculty $\left(X_{3}\right)$, Engeneering Faculty $\left(X_{4}\right)$ and Agriculture Faculty $\left(X_{5}\right)$ of Batanghari University significantly affect achievement motivation of leacturers of Pedagogics Faculty $\left(Y_{1}\right)$, Economics Faculty $\left(Y_{2}\right)$, Law Faculty $\left(Y_{3}\right)$, Engeneering Faculty $\left(Y_{4}\right)$ and Agriculture Faculty $\left(Y_{5}\right)$ of Batanghari University respectively. For this purpose, questionnaire was distributed to 77 respondents who were randomly selected from the five faculties to obtain data. Then, the data collected was analyzed by using simple correlation analysis of Pearson Product Moment and simple regression analysis. The t-test at the level of $95 \%$ was used to test the hypotheses. The result of the analysis shows that 1) $X_{1}$ is proved not to correlate significantly with $Y_{1}$. This means that dean's managerial skills have no affect on lecturers' achievement motivation in Pedagogics Faculty with contribution of only 5\%. This also means that dean's managerials skills cannot be used to improve lecturers' achievement motivation in Pedagogics Faculty, 2) $X_{2}$ is proved not to significantly correlate with $Y_{2}$. This means that dean's managerial skills have no affect on lecturers' achievement motivation in Economics Faculty with contribution of only $14 \%$. This also means that dean's managerial skills cannot be used to improve lecturers' achievement motivation in Economics Faculty, 3) $X_{3}$ is proved no to significantly correlate with $Y_{3}$. This means that dean's managerial skills have no affect on lecturers' achievement motivation in Law Faculty with contribution of only 19\%, This also means that dean's managerial skills cannot be used to improve lecturers' achievement motivation in Law Faculty, 4) $X_{4}$ is proved not to significantly correlate with $Y_{4}$. This means that dean's managerial skills have no affect on lecturers' achievement motivation in Engenerring Faculty with contribution of only 1\%. This also means that dean's managerial skills cannot be used to improve lecturers' achievement motivation in Engeeering Faculty, 5) $X_{5}$ is proved to correlate significantly with $Y_{5}$. This means that dean's managerial skills have significant affect on lecturers' achievement motivation in Agriculture Faculty with contribution of $56 \%$. This also means that dean's managerials skills can be used to improve lecturers' achievement motivation in Agriculture Faculty. Regression analysis shows that $Y_{5}=0.48+0.35\left(X_{5}\right)$. Ini berarti if dean's managerial skills of Agricultural Faculty $\left(X_{5}\right)$ increases by 1 then lecturers' achievement motivation of Agriculture Faculty $\left(Y_{5}\right)$ will increase by 0.39 .
\end{abstract}

Key Words: dean's managerial skills, lecturer's achievement motivation

\section{PENDAHULUAN}

Salah satu tujuan Perguruan Tinggi (PT) adalah menghasilkan lulusan yang bermutu tinggi. Untuk mencapai tujuan ini semua komponen yang ada di PT harus memiliki kualitas yang tinggi pula. Dua di antara komponen-komponen tersebut

${ }^{1}$ Dosen Fakultas Ekonomi Universitas Batanghari

Correlation of Lecturers' Achievement Motivation and Deans' Managerial Skills at Batanghari University 
adalah dosen dan dekan. Dosen, sesuai dengan konsep tridarma perguruan tinggi, memiliki tiga macam tugas utama yakni melakukan pengajaran kepada mahasiswa, melakukan penelitian, dan melakukan kegiatan pengabdian kepada masyarakat. Dekan merupakan top manager di fakultas. Tugas dekan adalah mengelola fakultas dengan baik agar tujuan fakultas sebagai salah satu unit kerja di universitas dapat tercapai dengan baik. Dengan kata lain, dekan dan dosen merupakan dua faktor penting dalam menghasilkan lulusan yang bermutu.

Motivasi berprestasi adalah dorongan yang dimiliki seseorang untuk bekerja lebih baik atau lebih unggul. Dosen, agar mampu menampilkan kinerja yang baik, harus memiliki motivasi berprestasi yang tinggi. Kemampuan manajerial adalah kemampuan menerapkan fungsi-fungsi manajemen dalam mengelola suatu organisasi. Secara teoritis, kemampuan manajerial pimpinan berpengaruh penting kepada motivasi berprestasi. Semakin tinggi kemampuan manajerial pimpinan semakin tinggi pula motivasi berprestasi bawahan. Sebaliknya, semakin rendah kemampuan manajerial pimpinan semakin rendah pula motivasi berprestasi bawahan.

Universitas Batanghari (Unbari) adalah salah satu perguruan tinggi swasta (PTS) yang berkedudukan di Kota Jambi. Unbari memiliki lima fakulta: Fakultas Keguruan dan Ilmu Pendidikan (FKIP), Fakultas Ekonomi (FE), Fakultas Hukum (FH), Fakultas Teknik (FT), dan Fakultas Pertanian (FP) dengan 15 buah program studi (Prodi). Saat ini, Unbari memiliki 188 orang dosen yang tersebar di 5 fakultas dengan latar belakang pendidikan, usia, kepangkatan, dan budaya yang bervariasi. Beberapa tahun terakhir diketahui bahwa Unbari mengalami kemajuan yang pesat baik secara kuantitas maupun secara kualitas. Perkembangan secara kuantitas terlihat dari semakin banyaknya jumlah mahasiswa yang kuliah di PTS ini. Perkembangan kualitas terlihat dari semakin banyaknya program studi yang terkreditasi B. Hal ini tidak terlepas dari kerja sama semua pihak terutama dekan dan dosen.

Berdasarkan penjelasan di atas dapat diyakni bahwa manajemen fakultas di lingkungan Unbari telah berfungsi dengan baik. Demikian pula dosen telah memiliki motivasi berprestasi yang baik. Namun demikian, sejauh pengamatan peneliti belum ada bukti empris tentang bagaimana hubungan kedua variable ini terutama di lingkungan Unbari. Penelitian ini bertujuan untuk menjelaskan secara empiris bagaimana kemampuan manajerial dekan bepengaruh secara signifikan dengan motivasi berprestasi dosen.

Karena keterbatasan waktu, biaya, dan kemampuan peneliti, permasalahan dalam penelitian ini dibatasi kepada hanya dua variabel pokok saja yakni: 1) tingkat persepsi dosen terhadap kemampuan manajerial dekan, yang mencakup: (a) kemampuan perencanaan, (b) kemampuan pengorganisasian, (c) kemampuan kepemimpinan, dan (d) kemampuan pengendalian, dan 2) motivasi berprestasi dosen, yang mencakup: (a) aspek frekwensi perkuliahan, (b) aspek proses perkuliahan, (c) aspek pelayanan kepada mahasiswa, dan (d) aspek partisipasi difakultas.

Dengan demikian, masalah dalam penelitian ini dapat dirumuskan sebagai berikut: 1) Bagaiamana tingkat persepsi dosen terhadap kemampuan manajerial dekan di lingkungan Unbari? 2) Bagaiaman tingkat motivasi berprestasi dosen di lingkungan Unbari? 3) Apakah terdapat hubungan yang positif dan signifikan antara tingkat persepsi dosen terhadap kemampuan manajerial dekan di lingkungan Unbari dengan tingkat motivasi berprestasi dosen? 
Sejalan dengan rumusan masalah maka tujuan penelitian ini adalah 1) untuk mengetahui bagaiamana tingkat persepsi dosen terhadap kemampuan manajerial dekan di lingkungan Unbari, 2) untuk mengetahui bagaimana tingkat motivasi berprestasi dosen di lingkungan Unbari, dan 3) untuk mengetahui apakah terdapat hubungan yang positif dan signifikan antara tingkat persepsi dosen terhadap kemampuan manajerial dekan di lingkungan Unbari dengan tingkat motivasi berprestasi dosen di lingkungan Unbari.

Hasil penelitian ini diharapkan bermanfaat secara teoritik maupun secara praktis:

1. Manfaat Teoritik

Secara teoritik, hasil penelitian ini dapat bermanfaat bagi pengembangan ilmu manajemen sumber daya manusia khususnya teori hubungan motivasi berprestasi bawahan dengan kemampuan manajerial atasan.

2. Manfaat Praktis

Secara praktis, hasil penelitian ini diharapkan bermanfaat bagi pihakpihak yang berkepentingan seperti:

a. bagi pengelola perguruan tinggi khususnya Unbari dalam mengembangkan motivasi berprestasi dosen.

b. bagi dosen sebagai umpan balik dalam meningkatkan motivasi mereka.

1. Definisi dan Konsep

\section{LANDASAN TEORITIS}

a. Motivasi Berprestasi

Taylor mengemukakan bahwa orang termotivasi untuk bekerja untuk mendapatkan uang oleh sebab itu mereka harus diawasi secara ketat. McGregor mengemukakan teori motivasi dengan istilah Teori $\mathrm{X}$ dan teori Y. Menurut teori X, orang tidak suka bekerja, sedangkan menurut teori $\mathrm{Y}$ orang bersedia melakukan pekerjaan apabila dengan demikian dia akan mendapat imbalan dari hasil pekerjaannya. Maslow mengemukakan teori kebutuhan yang mengatakan bahwa orang termotivasi untuk melakukan pekerjaan karena terdorong oleh keinginan untuk memenuhi kebutuhan yang tersusun secara hirarkis. Herzberg mengemukakan teori dua faktor yakni Hygine factor yang mengatakan bahwa menurunnya ketidakpuasan dalam kerja tidak menunjukkan adanya kenaikan motivasi, dan faktor motivasi yang mengatakan bahwa tidak adanya motivasi kerja tidak selalu berarti mengakibatkan ketidakpuasan.

Menurut teori keadilan, seseorang termotivasi untuk melakukan capaian baru kemudian mempertahankan rasa keadilan. Teori harapan mengatakan motivasi kerja kita tergantung pada seberapa besar kita menginginkan sesuatu dan seberapa mungkin kita dapat mencapainya.

Definisi-definisi di atas memperlihatkan persamaan yang mendasar meskipun menggunakan rumusan yang berbeda-beda. Persamaan-persamaan tersebut antara lain adalah motivasi merupakan faktor penggerak bagi seseorang untuk bekerja. Faktor penggerak tersebut dapat berasal dari diri sendiri seperti keinginan untuk memenuhi kebutuhan atau dari luar seperti imbalan yang diterima atas pekerjaan tersebut. Dengan demikian, motivasi dapat didefinisikan sebagai faktor yang menggerakkan, mengarahkan, dan mempertahankan perilaku seseorang terhadap suatu kegiatan. 
b. Kemampuan Manajerial

Menurut Pride, et.al. (1988), fungsi dasar manajemen adalah 1) goal setting and planning yakni fungsi menetapkan tujuan atau sasaran organisasi dan menetapkan kegiatan sebagai strategi pencapaian sasaran tersebut, 2) organizing yakni fungsi mengatur dan mengelompokkan sumberdaya dan kegiatan untuk mencapai tujuan yang telah ditetapkan, 3) leading and motivating yakni fungsi mempengaruhi, mengarahkan dan memotivasi anggota organisasi agar bekerja lebih baik untuk mencapai tujuan, 4) controlling yakni fungsi mengawasi, mengevaluasi, dan meregulasi kegiatan yang sedang berjalan. Lebih lanjut Pride, et.al. mengkategorikan peran (role) manajer ke dalam tiga kategori yakni 1) desicional roles yakni peran mengambil keputusan, 2) interpersonal roles yakni peran berhubungan dengan oran lain, dan 3) informational roels yakni peran menjadi sumber informasi bagi anggota organisasi. Untuk menjalankan tugas-tugas ini, diperlukan lima macam keterampilan. Kelima keterampilan tersebut adalah 1) keterampilan teknikal yakni keterampilan khusus yang diperlukan untuk melaksanakan tugas tertententu. Misalnya keterampilan mengoperasikan komputer bagi operator komputer untuk melaksanakan tugas-tugasnya, 2) keterampilan konseptual yakni kemampuan berpikir abstrak seperti kemampuan melihat secara komprehensip berbagai unsur orgaisasi menjadi suatu kesatuan, 3) keterampilan interpersonal yakni kemampuan berhubungan dengan orang lain misalnya kemampuan berkomunikasi secara efektif, kemampuan memahmi perasaan orang lain, dan kemampuan menjalin relasi dengan orang lain, 4) keterampilan diagnostik yakni keterampilan mengidentifikasi masalah dan menentukan penyebabnya, 5) keterampilan analitik yakni keterampilan menganalisis berbagai aspek atau isu yang ada dalam sebuah organisasi misalnya kemampuan melihat kaitan antara satu aspek dengan aspek yang lain.

Robbins dan Coulter (2004) mengatakan apa yang dikerjakan manajer dapat dilihat berdasarkan fungsi manajemen, peran manajerial, dan keterampilan manajerial. Fungsi manajemen terdiri dari 1) fungsi perencanaan yakni fungsi mendefinisikan sasaran, menetapkan strategi untuk mencapai sasaran, dan menyusun rencana untuk mengintegrasikan dan mengkoordinasikan sejumlah kegiatan, 2) fungsi pengorganisasian yakni fungsi pengaturan dan pengelompokan tugas-tugas, dan penetapan siapa melaksanakan tugas dan garis wewenang dan tanggung jawab, 3) fungsi kepemimpinan yakni fungsi mempengaruhi dan memotivasi bawahan, mengarahkan, dan memecahkan berbagai masalah terkait perilaku bawahan, 4) fungsi pengendalian yakni fungsi monitoring dan evaluasi untuk mengetahui bahwa segala sesuatu yang telah direncanakan berjalan dengan baik.

Lebih lanjut, Robbins dan Coutler mengatakan peran manajerial adalah: 1) peran antar pribadi (interpersonal role) yakni peran berhubungan dengan orang lain dan peran-peran yang bersifat seremonial dan simbolis, 2) peran informasional (informasional role) yakni peran yang meliputi menerima, mengumpulkan dan membagikan informasi kepada anggota organisasi, 3) peran pengambilan keputusan (decisional role) yakni peran yang berkaitan dengan membuat pilihan-pilihan. 
Untuk menjalankan tugas dan kegiatan manajerial ini diperlukan beberapa keahlian. Menurut Robbins dan Coutler terdapat tiga macam keahlian yang diperlukan yakni 1) keahliah teknis yakni pengetahuan dan kemahiran tertentu misalnya pengetahuan dan kemahiran di bidang akuntansi, komputer, hukum, dan lain sebaginya, 3) keahlian tentang orang (keahlian interpersonal) yakni keahlian berhubungan dan bekerja sama dengan orang lain baik secara individu maupun kelompok.

Dari dua pendapat di atas dapat disimpulkan bahwa kemampuan manajerial adalah kemampuan yang harus dikuasai oleh seorang manajer untuk melaksanakan kegiatannya dalam menjalankan fungsi dan proses manajemen.

2. Hasil Penelitian yang Relevan

Penelitian yang dilakukan oleh Simarmata (2002) yang dilakukan di Universitas Batanghari dan dipublikasikan di Jurnal Akademika (Volume 6 No 1 April 2002) menemukan bahwa tingkat rata-rata kinerja dosen Unbari adalah sedang dan tingkat rata-rata motivasi mereka adalah juga sedang. Terdapat empat variable motivasi yang diteliti untuk menggambarkan faktor-faktor yang berpengaruh terhadap tingkat kinerja tersebut. Keempat faktor tersebut didasarkan kepada teori kebutuhan Maslow yakni faktor pemenuhan kebutuhan pokok, faktor pengakuan dari pimpinan, faktor kebutuhan sosial, dan faktor kesempatan berkembang. Dari hasil analisis korelasi yang dilakukan ditemukan bahwa keempat faktor tersebut secara bersama-sama berkorelasi dengan kinerja dosen. Namun, secara parsial hanya faktor kesempatan berkembang yang berpengaruh terhadap kinerja dosen. Ini menunjukkan bahwa dosen-dosen di Unbari melihat bahwa Unbari dapat menjadi sarana bagi dosen-dosen untuk berkembang. Tiga faktor lain yakni faktor pemenuhan kebutuhan pokok yang dinyatakan dengan besaran gaji, faktor pengakuan dari pimpinan, dan faktor kebutuhan sosial tidak berkorelasi dengan kinerja dosen. Ini juga berarti bahwa gaji, penghargaan (dalam bentuk reward), dan hubungan sosial sesama dosen dianggap bukan merupakan faktor penting dalam meningkatkan kinerja dosen.

3. Kerangka Berpikir

Universitas adalah sebuah organisasi. Disebut sebuah organisasi karena ubiversitas memiliki komponen-komponen yang harus saling bekerja sama, berinteraksi satu sama lain untuk mencapaia tujuan yang telah ditetapkan yakni menghasilkan lulusan yang bermutu tinggi. Dua dari komponen-kmponen tersebut adalah dekan dan dosen. Dekan berperan sebagai pengelola fakultas. Untuk itu, seorang dekan harus memiliki kemampuan amanjerial yang cukup handal agar dapat mengelola fakultas secara efektif dan efisien. Sementara itu, dosen bertugas untuk melayani mahasiswa dalam bentuk jkegiatan kuliah. Untuk melaksanakan perkuliahan yang bermutu tinggi, seorang dosen perlu memiliki motivasi yang tinggi untuk bekerja lebih unggul

Salah satu faktor yang mempengruhi motivasi dosen untuk bekerja lebih unggul adalah kemampuan manajerial dekan. Semakin tinggi kemampuan manajerial dekan semakin tinggi pula motivasi berprewtasi dosen. Sebaliknya, semakin rendah kemampuan manajerial dekan semakin rendah pula motivasi berprestasi dosen. 
1. Jenis Penelitian

\section{METODOLOGI PENELITIAN}

Penelitian ini adalah penelitian deskriptif kuantitatif dengan pendekatan survei. Dikatakan penelitian deskriptif karena penenlitian ini hanya menjelaskan fenomena yang terjadi saat ini.

2. Populasi dan Sampel Penelitian

Populasi dari penelitian ini adalah semua dosen tetap Unbari dengan masa tugas minimal satu tahun. Kriteria satu tahun ini ditetapkan dengan alasan agar semua populasi telah mengenal dekan dengan baik. Sedangkan sampel diambil dengan teknik acak sederhana berkelompok (cluster simple random) Teknik ini digunakan dengan pertimbangan bahwa populasi tersebar di lima fakultas.

3. Variabel Penelitian

Dalam penenlitian ini terdapat dua macam variable, yakni variable (X) dan variable (Y). Variabel (X) yang juga disebut variable predictor adalah persepsi dosen terhadap tingkat kemampuan manajerial dekan di lingkungan Universitas Batanghari (Unbari) ditinjau dari emapt dimensi yakni kemampuan merencanakan, kemampuan mengorganisasikan, kemampuan memimpin dan kemampuan mengendalikan. Variabel $(Y)$ yang juga disebut dengan variable kriterium adalah tingkat motivasi berprestasi dosen ditinjau dari empat dimensi yakni: keinginan meningkatkan frekwensi perkuliahan, keinginan meningkatkan kualitas proses perkuliahan, keinginan meningkatkan pelayanan kepada mahasiswa, dan keinginan meningkakan partisipasi di fakultas.

4. Definisi Operasional Variabel

a. Persepsi Dosen terhadap Kemampuan Manajerial Dekan

Persepsi dosen terhadap kemampuan manajerial dekan adalah skor tentang persepsi dosen terhadap kemampuan manajerial dekan di lingkungan Unbari untuk melaksanakan fungsi-fungsi manajemen yang diukur dengan angket dan diisi oleh dosen di fakultas masing-masing.

b. Motivasi Berprestasi Dosen

Motivasi berprestasi dosen adalah skor tentang dorongan yang dimiliki atau usaha yang dilakukan oleh dosen Unbari untuk meningkatkan frekwensi perkuliahan, mutu proses perkuliahan, mutu pelayanan kepada mahasiswa, dan tingkat partisipasi di fakultas yang diukur dengan angket yang diisi oleh dosen yang bersangkutan.

5. Instrumen Penelitian

Untuk mengumpulkan data kedua variable tersebut digunakan angket yang dikembangkan sendiri oleh peneliti. Angket terdiri dari 12 pernyataan untuk variable $(\mathrm{X})$ dengan skala $1-5$, dan 11 pernyataan untuk variable $(\mathrm{Y})$ dengan skala $1-5$. Semakin kecil skala maka semakin kecil skor atau sebaliknya semakin besar skala semakin besar skor.

6. Teknik Analisis

a. Analisis Deskriptif

Analisis deskriptif dilakukan untuk memperoleh gambaran karakteristik responden dan skor setiap variable yang diteliti. Analisis deskriptif meliputi penyajian data dalam bentuk table distribusi frekuensi.

b. Analisis Inferensial

Analisis inferensial terdiri dari koefisien korelasi, koefisien diterminansi, dan uji signifikansi. Koefisien korelasi bertujuan untuk 
mengambarkan arah hubungan korelasi kedua variable. Jika koefisien korelasi adalah positif maka dapat disimpulkan bahwa kedua variable memiliki korelasi yang positif yang rtinya jika variable $(\mathrm{X})$ meningkat maka variable (Y) juga meningkat. Sebaliknya jika koefisien korelasi adalah negatif maka dapat disimpulkan bahwa kedua variable memiliki hubungan yang negatif yang artinya jika variable $(\mathrm{X})$ meningkat maka variable $(\mathrm{Y})$ menurun. Analisis korelasi yang digunakan adalah analisis korelasi product moment Pearson, dengan rumus sebagai berikut:

$$
r_{X i Y}=\frac{\mathrm{n}\left(\sum X i Y\right)-\left(\sum X i\right)\left(\sum Y\right)}{\sqrt{\left\{n\left(X i^{2}\right)-(X i)^{2}\right\}\left\{n\left(\sum Y^{2}\right)-(Y)^{2}\right\}}}
$$

Koefisien diterminansi bertujuan untuk melihat seberpa besar variable (X) dapat menjelaskan perubahan pada variable $(\mathrm{Y})$ dengan rumus $\mathrm{R}^{2}=(\mathrm{r})^{2}$ $\mathrm{x} 100 \%$. Untuk membuktikan signifikansi korelasi digunakan uji $\mathrm{t}$ dengan ketentuan sebagai berikut:

1) Ho ditolak atau Ha diterima apabila harga t-hitung lebih besar daripada harga $t$-tabel atau $t_{h}>t_{t}$, pada taraf signifikansi $95 \%$ atau $\alpha=0.05$. Ini berarti dugaan yang mengatakan bahwa kemampuan manajerial dekan berkorelasi secara signifikan dengan motivasi berprestasi dosen terbukti dan harus diterima.

2) Ho diterima atau Ha ditolak apabila harga t-hitung lebih kecil daripada harga $t$-tabel atau $t_{h}<t_{t}$, pada taraf signifikansi 95\% atau $\alpha=0.05$. Ini berarti dugaan yang mengatakan bahwa kemampuan manajerial dekan berkorelasi secara signifikan dengan motivasi berprestasi dosen tidak terbukti dan harus ditolak.

\section{HASIL PENELITIAN DAN PEMBAHASAN}

1. Deskripsi Data

a. Karakteristik Responden

Analisis data secara deskriptif tentang karakteristik responden berdasarkan angket yang disebarkan kepada 77 orang responden dapat dilihat pada table berikut:

Tabel 1

Karakteristik Responden menurut Jenis Kelamin

\begin{tabular}{llcccccc}
\hline \multirow{2}{*}{ No } & \multirow{2}{*}{ Fakultas } & \multicolumn{2}{c}{ Lenis Kelamin } & & \multirow{2}{*}{ Perempuan } & Total & $\%$ \\
& & Jumlah & $\%$ & Jumlah & $\%$ & & \\
\hline 1 & KIP & 6 & 30 & 14 & 70 & 20 & 25,98 \\
2 & Ekonomi & 7 & 47 & 8 & 53 & 15 & 19,48 \\
3 & Hukum & 8 & 53 & 7 & 47 & 15 & 19,48 \\
4 & Teknik & 9 & 60 & 6 & 40 & 15 & 19,48 \\
5 & Pertanian & 5 & 42 & 7 & 58 & 12 & 15,58 \\
& Total & 35 & 45 & 42 & 55 & 77 & 100,00 \\
\hline
\end{tabular}

Dari table di atas terlihat bahwa jumlah responden sebanyak 77 orang sebagian besarnya adalah perempuan sebesar 55\% sedangkan laki-laki 
hanya $45 \%$. Namun bila dilihat per fakultas, responden di dua fakultas yakni fakultas hukum dan teknik jumlah responden didominasi laki-laki yakni sebanyak 53\% dan 60\% masing-masing.

b. Kemampuan Manajerial Dekan menurut Persepsi Dosen (Variabel X)

Angket yang digunakan untuk mengumpulkan data persepsi dosen terhadap kemampuan manajerial dekan di lingkungan Unbari terdiri dari 12 pernyataan dengan skala $1-5$. Dengan demikian, skor teoritik tertinggi adalah $5 \times 12=60$, dan skor teoritik terendah adalah $1 \times 12=12$. Sebaran angka (range) adalah $60-12=48$. Interval (i) ditetapkan 5 sesuai dengan jumlah tingkat kemampuan, yakni sangat tinggi (ST), tinggi (T), sedang (S), rendah $(\mathrm{R})$, dan sangat rendah (SR). Kelas interval (Ki) adalah $48: 5=9,6$ dibulatkan 10. Dengan demikian, distribusi frekwensi tingkat kemampuan manajerial dekan menurut persepsi dosen dapat dibuat seperti pada table berikut.

Tabel 2

Sebaran Skor Tingkat kemampuan Manajerial Dekan

\begin{tabular}{clc}
\hline No & \multicolumn{1}{c}{ Kategori Tingkat Kemampuan } & Rentang Skor \\
\hline 1 & Sangat tinggi & $55-65$ \\
2 & Tinggi & $44-54$ \\
3 & Sedang & $33-43$ \\
4 & Rendah & $23-32$ \\
5 & Sangat rendah & $12-22$ \\
\hline
\end{tabular}

Jumlah responden di FKIP adalah 20 orang. Dari tabulasi data diketahui total skor adalah 880. Dengan demikian skor rata-rata adalah 880 : $20=44$. Jumlah responden di FE adalah 15 orang. Dari tabulasi data diketahui total skor adalah 600. Dengan demikian skor rata-rata adalah 600 : $15=40$. Jumlah responden di FH adalah 15 orang. Dari tabulasi data diketahui total skor adalah 752. Dengan demikian skor rata-rata adalah 752 : $15=50,1$ dibulatkan 50. Jumlah responden di FT adalah 15 orang. Dari tabulasi data diketahui total skor adalah 639. Dengan demikian skor ratarata adalah $639: 15=42,6$ dibulatkan 43. Jumlah responden di FP adalah 12 orang. Dari tabulasi data diketahui total skor adalah 644. Dengan demikian skor rata-rata adalah $644: 12=53,7$ dibulatkan 54. Untuk lebih jelasnya skor rata-rata variable $(\mathrm{X})$ di setiap fakultas dapat di lihat pada table berikut:

Tabel 3

Skor Rata-rata Tingkat Kemampuan Manajerial Dekan

\begin{tabular}{clccccl}
\hline No & Fakultas & $\begin{array}{c}\text { Variabel } \\
\text { yang diteliti }\end{array}$ & $\begin{array}{c}\text { Jumlah } \\
\text { responden }\end{array}$ & Total skor & Rerata & Keterangan \\
\hline 1 & KIP & $\mathrm{X}_{1}$ & 20 & 880 & 44 & Tinggi \\
2 & Ekonomi & $\mathrm{X}_{2}$ & 15 & 600 & 40 & Sedang \\
3 & Hukum & $\mathrm{X}_{3}$ & 15 & 752 & 50 & Tinggi \\
4 & Teknik & $\mathrm{X}_{4}$ & 15 & 639 & 43 & Sedang \\
5 & Pertanian & $\mathrm{X}_{5}$ & 12 & 644 & 54 & Tinggi \\
\hline
\end{tabular}


Dari Tabel di atas terlihat responden yang menilai tingkat kemampuan manajerial dekan menurut penilaian responden di FKIP, FH, dan FP adalah tinggi, sedangkan di FE dan FT adalah sedang.

c. Motivasi Berprestasi Dosen

Angket yang digunakan untuk mengumpulkan data motivasi berprestasi dosen (Y) di lingkungan Unbari terdiri dari 11 pernyataan dengan skala $1-5$. Dengan demikian, skor teoritik tertinggi adalah 5 x $11=$ 55 , dan skor teoritik terendah adalah 1 x $11=11$. Sebaran angka (range) adalah $55-11=44$. Interval (i) ditetapkan 5 sesuai dengan jumlah tingkat motivasi, yakni sangat tinggi (ST), tinggi (T), sedang (S), rendah (R), dan sangat rendah (SR). Kelas interval $(\mathrm{Ki})$ adalah $44: 5=8,8$ dibulatkan 9. Dengan demikian, distribusi frekwensi tingkat motivasi berprestasi dosen di lingkungan Unbari dapat dibuat seperti pada table berikut.

Tabel 4

Sebaran skor Tingkat Motivasi Berprestasi Dosen

\begin{tabular}{clc}
\hline No & \multicolumn{1}{c}{ Kategori Tingkat Motivasi } & Rentang skor \\
\hline 1 & Sangat Tinggi & $51-60$ \\
2 & Tinggi & $41-50$ \\
3 & Sedang & $31-40$ \\
4 & Rendah & $21-30$ \\
5 & Sangat rendah & $11-20$ \\
\hline
\end{tabular}

Jumlah responden di FKIP adalah 20 orang. Dari tabulasi data diketahui total skor adalah 856. Dengan demikian skor rata-rata adalah 856 : $20=42,8$ dibulatkan 43. Jumlah responden di FE adalah 15 orang. Dari tabulasi data diketahui total skor adalah 610. Dengan demikian skor ratarata adalah $610: 15=40,7$ dibulatkan 41. Jumlah responden di $\mathrm{FH}$ adalah 15 orang. Dari tabulasi data diketahui total skor adalah 656. Dengan demikian skor rata-rata adalah $656: 15=43,7$ dibulatkan 44. Jumlah responden di FT adalah 15 orang. Dari tabulasi data diketahui total skor adalah 643. Dengan demikian skor rata-rata adalah $643: 15=42,9$ dibulatkan 43. Jumlah responden di FP adalah 12 orang. Dari tabulasi data diketahui total skor adalah 536. Dengan demikian skor rata-rata adalah 536 : $12=44,7$ dibulatkan 45 . Untuk lebih jelasnya skor rata-rata variable (Y) di setiap fakultas dapat di lihat pada table berikut:

Tabel 5

Skor Rata-rata Tingkat Motivasi Berprestasi Dosen

\begin{tabular}{clccccc}
\hline No & Fakultas & $\begin{array}{c}\text { Variabel } \\
\text { yang diteliti }\end{array}$ & $\begin{array}{c}\text { Jumlah } \\
\text { responden }\end{array}$ & Total skor & Rerata & Keterangan \\
\hline 1 & KIP & $\mathrm{Y}_{1}$ & 20 & 856 & 43 & Tinggi \\
2 & Ekonomi & $\mathrm{Y}_{2}$ & 15 & 610 & 41 & Tinggi \\
3 & Hukum & $\mathrm{Y}_{3}$ & 15 & 656 & 44 & Tinggi \\
4 & Teknik & $\mathrm{Y}_{4}$ & 15 & 643 & 43 & Tinggi \\
5 & Pertanian & $\mathrm{Y}_{5}$ & 12 & 536 & 45 & Tinggi \\
\hline
\end{tabular}


Dari Tabel di atas terlihat bahwa tingkat rata-rata motivasi berprestasi dosen di lingkungan Unbari adalah tinggi di semua fakultas menurut penilaian responden.

\section{Uji Hipotesis}

Hasil uji hipotesis yang terdiri dari analisis korelasi dan uji signifikansi antara variable independen $(\mathrm{X})$ dengan variable dependen $(\mathrm{Y})$ dapat dilihat pada table berikut:

Tabel 6

Hasil Analisis Koefisien Korelasi, Koefisien Diterminasi, dan Uji Signifikansi

\begin{tabular}{llcccc}
\hline No & Fakultas & Variabel yang diuji & $\begin{array}{c}\text { Harga r- } \\
\text { hitung }\end{array}$ & $\begin{array}{c}\text { Harga } \\
\mathrm{R}^{2}\end{array}$ & $\begin{array}{c}\text { Harga t- } \\
\text { hitung }\end{array}$ \\
\hline 1 & KIP & $\mathrm{X}_{1}$ dan $\mathrm{Y}_{1}$ & 0,288 & $5 \%$ & 0,993 \\
2 & Ekonomi & $\mathrm{X}_{2}$ dan $\mathrm{Y}_{2}$ & 0,376 & $14 \%$ & 1,462 \\
3 & Hukum & $\mathrm{X}_{3}$ dan $\mathrm{Y}_{3}$ & 0,437 & $19 \%$ & 1,948 \\
4 & Teknik & $\mathrm{X}_{4}$ dan $\mathrm{Y}_{4}$ & 0,112 & $1 \%$ & 0,406 \\
5 & Pertanian & $\mathrm{X}_{5}$ dan $\mathrm{Y}_{5}$ & 0,747 & $56 \%$ & 3,552 \\
\hline
\end{tabular}

Analisis korelasi terhada $\mathrm{X}_{1}$ dan $\mathrm{Y}_{1}$ menunjukkan bahwa $\mathrm{r}=0,288$. Pada table terlihat bahwa $\mathrm{r}=0,468$ pada taraf signifikansi $5 \%$ dan $\mathrm{dk}=18$ Ini berarti r-hitung lebih kecil daripada r-tabel atau $0,288<0,468$. Dengan demikian terbukti bahwa kedua variabel memiliki tingkat korelasi yang rendah. Uji signifikansi t menunjukkan bahwa nilai t-hitung 0,993 lebih kecil daripada nilai t-tabel 2,101 pada taraf signifikansi $\alpha=0,05 \mathrm{dan} \mathrm{dk}=18$ yang berarti korelasi kedua variable tidak signifikan. Nilai $\mathrm{R}^{2}=5 \%$, artinya hanya $5 \%$ variasi $\mathrm{Y}_{1}$ dapat dijelaskan oleh $\mathrm{X}_{1}$. Variasi lainnya sebesar $95 \%$ dijelaskan oleh faktor lain yang tidak diteliti dalam penelitian ini.

Analisis korelasi terhada $\mathrm{X}_{2}$ dan $\mathrm{Y}_{2}$ menunjukkan bahwa $\mathrm{r}=0,376$. Pada table terlihat bahwa $\mathrm{r}=0,553$ pada taraf signifikansi $5 \%$ dan $\mathrm{dk}=13$. Ini berarti r-hitung lebih kecil daripada r-tabel atau $0,376<0,553$. Dengan demikian terbukti bahwa kedua variable terbukti memiliki tingkat korelasi yang rendah. Uji signifikansi t menunjukkan bahwa nilai t-hitung 1,462 lebih kecil daripada nila t-tabel 2,160 pada taraf signifikansi $\alpha=0,05$ dan $\mathrm{dk}=13$ yang berarti korelasi kedua variable tidak signifikan. Nilai $\mathrm{R}^{2}=14 \%$, artinya hanya $14 \%$ variasi $\mathrm{Y}_{2}$ dapat dijelaskan oleh $\mathrm{X}_{2}$. Variasi lainnya sebesar $86 \%$ dijelaskan oleh faktor lain yang tidak diteliti dalam penelitian ini.

Analisis korelasi terhada $\mathrm{X}_{3}$ dan $\mathrm{Y}_{3}$ menunjukkan bahwa $\mathrm{r}=0,437$. Pada table terlihat bahwa $\mathrm{r}=0,553$ pada taraf signifikansi $5 \%$ dan $\mathrm{dk}=13$. Ini berarti r-hitung lebih kecil daripada r-tabel atau $0,437<0,553$. Dengan demikian terbukti bahwa kedua variable memiliki tingkat korelasi yang rendah. Uji signifikansi t menunjukkan bahwa nilai t-hitung 1,948 lebih kecil daripada nilai t-tabel 2,160 pada taraf signifikansi $\alpha=0,05$ dan $\mathrm{dk}=13$ yang berarti korelasi kedua variable tidak signifikan. Nilai $\mathrm{R}^{2}=19 \%$, artinya hanya $19 \%$ variasi $\mathrm{Y}_{3}$ dapat dijelaskan oleh $\mathrm{X}_{3}$. Variasi lainnya sebesar $81 \%$ dijelaskan oleh faktor lain yang tidak diteliti dalam penenlitian ini.

Analisis korelasi terhada $\mathrm{X}_{4}$ dan $\mathrm{Y}_{4}$ menunjukkan bahwa $\mathrm{r}=0,0,112$. Pada table terlihat bahwa $\mathrm{r}=0,553$ pada taraf signifikansi $5 \%$ dan $\mathrm{dk}=13$. Ini berarti r-hitung lebih kecil daripada r-tabel atau $0,112<0,553$. Dengan demikian terbukti bahwa kedua variable memiliki tingkat korelasi yang sangat 
rendah. Uji signifikansi t menunjukkan bahwa niali t-hitung 0,406 lebih kecil daripada nilai t-tabel 2,160 pada taraf signifikansi $\alpha=0,05$ dan $\mathrm{dk}=13$ yang berarti korelasi kedua variable tidak signifikan. Nilai $\mathrm{R}^{2}=1 \%$, artinya hanya $1 \%$ vriasi $\mathrm{Y}_{4}$ dapat dijelaskan oleh $\mathrm{X}_{4}$. Variasi lainnya sebesar $99 \%$ dijelaskan oleh faktor lain yang tidak diteliti dalam penelitian ini.

Analisis korelasi terhada $\mathrm{X}_{5}$ dan $\mathrm{Y}_{5}$ menunjukkan bahwa $\mathrm{r}=0,747$. Pada table terlihat bahwa $\mathrm{r}=0,632$ pada taraf signifikansi $5 \%$ dan $\mathrm{dk}=10$. Ini berarti r-hitung lebih besar daripada r-tabel atau 0,747>0,632. Dengan demikian terbukti bahwa kedua variable memiliki tingkat korelasi yang tinggi. Uji signifikansi t menunjukkan bahwa nilai t-hitung 3,552 lebih besar daripada nilai t-tabel 2,228 pada taraf signifikansi $\alpha=0,05 \mathrm{dan} \mathrm{dk}=10$ yang berarti korelasi kedua variable adalah signifikan. Nilai $\mathrm{R}^{2}=56 \%$, artinya $56 \%$ variasi $\mathrm{Y}_{5}$ dapat dijelaskan oleh $\mathrm{X}_{5}$. Dengan demikian dapat diteruskan ke analisis regresi. Analisis regresi terhadap variable X5 dengan Y5 menunjukkan bahwa nilai $\mathrm{a}=0,48$ dan $\mathrm{b}=0,35$. Dengan demikian model regresi dapat dibuat sebagai berikut:

$$
\begin{aligned}
\mathrm{Y} & =\mathrm{a}+\mathrm{bX} \\
& =0,48+0,35(\mathrm{X})
\end{aligned}
$$

Ini berarti bila $\mathrm{X}$ mengalami peningkatan 1 atau $100 \%$ maka $\mathrm{Y}$ akan mengalami peningkatan sebesar 0,35 atau $35 \%$.

\section{PEMBAHASAN}

Dari analisis deskriptif terhadap data penelitian di FKIP diketahui bahwa tingkat kemampuan manajerial dekan FKIP menurut persepsi dosen FKIP adalah tinggi dan tingkat motivasi berprestasi dosen-dosen di lingkungan FKIP adalah juga tinggi. Ini berarti dosen-dosen di FKIP menilai bahwa dekan FKIP saat ini mampu mengelola fakultas dengan baik. Namun, analisis inferensial membuktikan bahwa kedua variable tidak memiliki korelasi yang signifikan dengan tingkat pengaruh hanya 5\%. Dengan demikian disimpulkan bahwa kemampuan manajerial dekan tidak dapat digunakan sebagai faktor penting dalam meningkatkan motivasi berprestasi dosen di lingkungan FKIP.

Dari analisis deskriptif terhadap data penelitian di Fakultas Ekonomi (FE) diketahui bahwa tingkat kemampuan manajerial dekan FE menurut persepsi dosen FE adalah sedang. Akan tetapi, tingkat motivasi berprestasi dosen-dosen di lingkungan FE adalah tinggi. Ini berarti dosen-dosen di FKIP menilai bahwa dekan FE saat ini mampu mengelola fakultas dengan tingkat sedang. Analisis inferensial membuktikan bahwa kedua variable tidak memiliki korelasi yang signifikan dengan tingkat pengaruh hanya $14 \%$. Dengan demikian disimpulkan bahwa kemampuan manajerial dekan FE tidak dapat digunakan sebagai faktor penting dalam meningkatkan motivasi berprestasi dosen di lingkungan FE.

Dari analisis deskriptif terhadap data penelitian di Fakultas Hukum (FH) diketahui bahwa tingkat kemampuan manajerial dekan FH menurut persepsi dosen $\mathrm{FH}$ adalah tinggi dan tingkat motivasi berprestasi dosen-dosen di lingkungan $\mathrm{FH}$ adalah juga tinggi. Ini berarti dosen-dosen di FH menilai bahwa dekan FH saat ini mampu mengelola fakultas dengan tingkat baik. Namun, analisis inferensial membuktikan bahwa kedua variable tidak memiliki korelasi yang signifikan dengan tingkat pengaruh hanya $15 \%$. Dengan demikian disimpulkan bahwa kemampuan manajerial dekan FH tidak dapat digunakan sebagai faktor penting dalam meningkatkan motivasi berprestasi dosen di lingkungan FH. 
Dari analisis deskriptif terhadap data penelitian di Fakultas Teknik (FT) diketahui bahwa tingkat kemampuan manajerial dekan FT menurut persepsi dosen FT adalah sedang. Akan tetapi, tingkat motivasi berprestasi dosen-dosen di lingkungan FT adalah tinggi. Ini berarti dosen-dosen di FT menilai bahwa dekan FT saat ini mampu mengelola fakultas dengan tingkat yang sedang. Analisis inferensial membuktikan bahwa kedua variable tidak memiliki korelasi yang signifikan dengan tingkat pengaruh hanya 19\%. Dengan demikian disimpulkan bahwa kemampuan manajerial dekan FT tidak dapat digunkan sebaga faktor penting dalam meningkatkan motivasi berprestasi dosen di lingkungan FT.

Dari analisis deskriptif terhadap data penelitian di Fakultas Pertenaian (FP) diketahui bahwa tingkat kemampuan manajerial dekan FP menurut persepsi dosen FP adalah tinggi dan tingkat motivasi berprestasi dosen-dosen di lingkungan FP adalah juga tinggi. Ini berarti dosen-dosen di FP menilai bahwa dekan FP saat ini mampu mengelola fakultas dengan baik. Analisis inferensial juga membuktikan bahwa kedua variable memiliki korelasi yang signifikan dengan tingkat pengaruh sebesar 56\%. Dengan demikian disimpulkan bahwa kemampuan manajerial dekan FP dapat digunkan sebaga salah satu faktor penting dalam meningkatkan motivasi berprestasi dosen-dosen di lingkungan FP. Bahkan analisis regresi menunjukkan bahwa bila tingkat kemampuan manajerial dekan mengalami kenaikan sebesar 1 atau $100 \%$ maka motivasi berprestasi dosen-dosen di lingkungan Unbari akan mengalami kenaikan sebesar 0,39 atau 39\%.

\section{Simpulan}

\section{SIMPULAN DAN SARAN}

Berdasarkan hasil analisis data yang telah dilakukan dapat diambil beberapa kesimpulan sebagai berikut:

1. Tingkat Motivasi berprestasi dosen di FKIP Unbari adalah $75 \%$ dantingkat kemampuan manajerial dekan FKIP menurut persepsi dosen FKIP adalah 74\% namun kedua variable ini terbukti tidak berkorelasi secara signifikan karena tingkat kekuatan korelasinya hanya 0,288 dan kontribusi kemampuan manajerial dekan terhadap motivasi berprestasi dosen hanya $5 \%$.

2. Tingkat Motivasi berprestasi dosen di FE Unbari adalah $75 \%$ dan tingkat kemampuan manajerial dekan FE menurut persepsi dosen FE adalah 65\% namun kedua variable ini terbukti tidak berkorelasi secara signifikan karena tingkat kekuatan korelasinya hanya 0,376 dan kontribusi kemampuan manajerial dekan terhadap motivasi berprestasi dosen hanya $14 \%$.

3. Tingkat Motivasi berprestasi dosen di FH Unbari adalah $76 \%$ dan tingkat kemampuan manajerial dekan FH menurut persepsi dosen $\mathrm{FH}$ adalah $79 \%$ namun kedua variable ini terbukti tidak berkorelasi secara signifikan karena tingkat kekuatan korelasinya hanya 0,437 dan kontribusi kemampuan manajerial dekan terhadap motivasi berprestasi dosen hanya $19 \%$.

4. Tingkat Motivasi berprestasi dosen di FT Unbari adalah $78 \%$ dan tingkat kemampuan manajerial dekan FP menurut persepsi dosen FP adalah 63\% namun kedua variable ini terbukti tidak berkorelasi secara signifikan karena tingkat kekuatan korelasinya sangat lemah yakni hanya 0,122 dan kontribusi kemampuan manajerial dekan terhadap motivasi berprestasi dosen hanya $1 \%$.

5. Tingkat Motivasi berprestasi dosen di FP Unbari adalah $81 \%$ dan tingkat kemampuan manajerial dekan FKIP menurut persepsi dosen FP adalah $81 \%$. Uji hipotesis membuktikan bahwa kedua variable ini memiliki korelasi yang 
kuat sebesar 0,747. Kobtribusi kemampuan manajerial dekan terhadap motivasi berprestasi dosen cukup besar yakni sebesar $56 \%$.

\section{Saran}

Berdasarkan temuan tersebut dapat disarankan beberapa hal sebagai berikut:

1. Untuk meningkatkan motivasi berprestasi dosen-dosen di Fakultas Pertanian (FP) dapat dilakukan dengan meningkatkan kompetensi manajerial dekan.

2. Untuk meningkatkan motivasi berprestasi dosen-dosen di Fakultas Keguruan dan Ilmu Pendidikan (FKIP), Fakultas Ekonomi (FE), Fakultas Hukum (FH), dan Fakultas Teknik (FT) dapat dilakukan dengan memanfaatkan faktor-faktor lain. Namun demikin kemampuan manajerial dekan masih tetap perlu ditingkatkan.

3. Perlu dilakukan penelitian yang lebih mendalam lagi untuk menentukan apa sesungguhnya faktor penentu motivasi berprestasi dosen di lingkungan Unbari.

\section{DAFTAR PUSTAKA}

Amir, Mohammad Faisal, Manajemen Kinerja Perguruan Tinggi, Jakarta: Mitra Wacana Media, 2016.

Amirullah, Kepemimpinan dan Kerja Sama Tim, Jakarta: Mitra Wacana Media, 2015.

Arwildayanto, Manajemen Sumber Daya Manusia Perguruan Tinggi, Bandung: Alfabeta, 2013.

Gellerman, Saul W., Motivasi dan Produktivitas, (Penerjemah: Soepomo S. Wardoyo), PT Pustaka Binaman Presindo, 1984.

Marsono, Metode Penelitian Kuantitatif, Bogor: Penerbit IN MEDIA, 2016.

Northhouse, Peter G., Kepemimpinan: Teori dan Praktek (Edisi Keenam) (Penerjemah: Dr. Ati Cahyani), Jakarta: PT Indeks Jakarta, 2013.

Pride, William M., et.al., Business (Second Edition), USA: Houghton Mifflin Company, 1988.

Robbins, Stephen P. and Coulter, Mary, Manajemen (Edisi ke-7 Jilid 1, Edisi Indonesia) (Alih Bahasa: T. Hermaya dan Harry Slamet), Jakarta: PT Indeks Jakarta, 2004.

Simarmata, Jonner, Korelasi Motivasi Kerja dengan Kinerja, Jurnal Akademika Volume 6 No.1 April 2002.

Sugiyono, Prof. Dr., Metode Penelitian Manajemen, Bandung: Penerbit Alfabeta, 2016.

Suyadi Prawirosentono dan Dewi Primasari, Kinerja \& Motivasi Karyawan, BPFE Yogyakarta, 2015.

Universitas Batanghari, Database Kepegawaian Tahun 2011

Tim Dosen Administrasi Pendidikan Universitas Pendidikan Indonesia, Manajemen Pendidikan, Bandung: Alfabeta, 2014.

Wibowo, Manajemen Kinerja (Edisi Kelima), Depok: PT Rajgrafindo Persada, 2007.

Wibowo, Budaya Organisasi: Sebuah Kebutuhan untuk Meningkatkan Kinerja Jangka Panjang (Edisi Kedua), Jakarta: Rajawali Pers, 2016.

Widoyoko, S. Eko Putro, Yeknik Penyusunan Instrumen Penenlitian, Yogyakarta: Pustaka Pelajar, 2016.

Wirawan, Kepemimpinan: Teori, Psikologi, Perilaku Organisasi, Aplikasi dan Penelitian, Depok: PT Rajagrafindo Persada, 2013. 